\title{
EFFECT OF INDIVIDUAL AND EMPLOYEES CHARACTERISTICS TO EMPLOYEE PERFORMANCE AT PTPN III (PERSERO) MEDAN
}

\author{
Muhammad Taufik Lesmana ${ }^{1}$, Asrizal Efendy NST ${ }^{2}$, Zuhri Aldino Nadeak ${ }^{3}$ \\ Management Studies Program Faculty of Economics and Business Universitas \\ Muhammadiyah Sumatera Utara (UMSU) \\ muhammadtaufiklesmana@gmail.com ${ }^{1}$,rizalmedan28@gmail.com ${ }^{2}$, \\ zuhrialdino@gmail.com ${ }^{3}$
}

\begin{abstract}
The purpose of this study is to determine the effect of individual characteristics on employee performance PTPN III (Persero) Medan, to determine the effect of work environment on employee performance PTPN III (Persero) Medan and to determine the influence of individual characteristics and work environment on employee performance PTPN III (Persero) Field. The population of this study is all employees of human resources department of PTPN III Medan, amounting to 51 people, while the sample in this study amounted to 51 people using saturated sampling. From the calculation, the model of regression equation is $Y=8.147+0.588 X \_1+0,155 X \_2$. From the results of multiple linear regression test above can be explained that the individual characteristics and work environment have a positive and significant effect on employee performance in PTPN III (Persero) Medan. Based on the above table note that the coefficient of individual characteristics gives a value of 0.588 and work environment coefficient gives a value of 0.155 which means that the better the individual characteristics and work environment then the employee performance on PTPN III (Persero) will increase.
\end{abstract}

\section{Keywords: Individual Characteristics, Work Environment and Employee Performance}

\section{PRELIMINARY}

\section{Background}

Good performance is the optimal performance, which is standardized performance and support the achievement of organizational goals. Improving employee performance will bring progress to the company to survive, therefore employee performance is the most serious challenge because success to achieve company goals and survival depends on the quality of human resources in it. According Ma'ruf Abdullah performance is a description of the level of achievement of the implementation of an activity or policy program in realizing organizational goals, objectives, vision and mission as outlined through strategic planning organization. Characteristics refer to the character and lifestyle of a person and the values that develop regularly so that the behavior becomes more consistent and easy to note. While the work environment is said to be good if employees can carry out activities optimally, healthy and comfortable. Conversely, if the work environment that is not considered to reduce employee morale, therefore by paying attention to a good working environment or create working conditions that are able to provide motivation to work it will bring influence on employee performance. This is appropriate according to Danang Sunyoto who states that the work environment is everything that is around the workers and who can influence himself in carrying out tasks that are charged such as lighting and others. Based on observations made found that the characteristics of individuals not in accordance with the expected, while the performance of employees for this is still quite low and employees still feel the work environment is less comfortable due to a narrow workspace.

\section{Formulation of The Problem}

a) Is there any influence of individual characteristics on employee performance at PTPN III (Persero) Medan. 
b) Is there any influence of work environment on employee performance at PTPN III (Persero) Medan.

c) Is there any influence of individual characteristics and work environment on employee performance at PTPN III (Persero) Medan.

\section{Research Objectives}

a) To determine the effect of individual characteristics on employee performance at PTPN III (Persero) Medan.

b) To know the effect of work environment on employee performance at PTPN III (Persero) Medan.

c) To know the influence of individual characteristics and work environment on employee performance at PTPN III (Persero) Medan.

\section{THEORETICAL FOUNDATION}

\section{The Understanding of Performance}

According Mangkunegara (2013: 67) said the performance is the result of work in quality and quantity achieved by an employee in performing their duties in accordance with the responsibilities given to him. While Moeheriono (2014: 95) said the performance or performance is a description of the level of achievement of the implementation of an activity or policy program in realizing the goals, vision and mission of an organization. Based on the above opinion can be concluded that the performance of employees is the result achieved by employees in the implementation of a job given to him in quantity and quality through procedures that focus on the goals to be achieved and with the fulfillment of standards of implementation in general.

\section{Factors Affecting Performance}

a) There are several factors that affect performance according to Edy Sutrisno (2011: 176-177): Effectiveness and efficiency

b) Authority and responsibility

c) Work discipline

\section{Understanding Individual Characteristics}

According Thoha (2008: 27) said that the characteristics of individuals is the behavior or character that exists in a person both positive and negative. These characteristics are very diverse, each company can certainly choose an employee who has good criteria and these characteristics must also be in accordance with what the company wants. Rivai (2006: 147) states that individual characteristics are special features, psychological properties, morals or character possessed by someone who distinguishes it from others.

\section{Factors Affecting Individual Characteristics}

There are several factors that affect individual characteristics, among others:
a) Biographical
b) Ability
c) Personality
d) Perception

\section{Understanding Work Environment}

Work environment is a very important component in employees doing work activities. Work environment has a direct influence on employee performance in completing the tasks assigned to him. According to Danang Sunyoto (2012: 43) states that the work environment is everything that is around the workers and who can mempegaruhi himself in carrying out tasks that are charged such as music, lighting and others. Meanwhile, according Sedarmayati (2007: 211) defines the work environment as follows: the work environment is the whole tooling tools and materials faced, the environment around which a person works, methods of work, and arrangement of work both as individuals and as a group. From the above definition can be concluded that the work environment is everything that is around employees at work, both physical and non-physical, directly or indirectly that can affect him and his work while working. 
Factors Affecting the Work Environment

a) Employee Relations

b) Noise Level of Work Environment

c) Lighting

d) Work Regulations

e) Air Circulation

f) Security

\section{Conceptual Framework}

Relationship of individual characteristics and work environment with employee performance can be seen in the research paradigm in Figure 1 below:

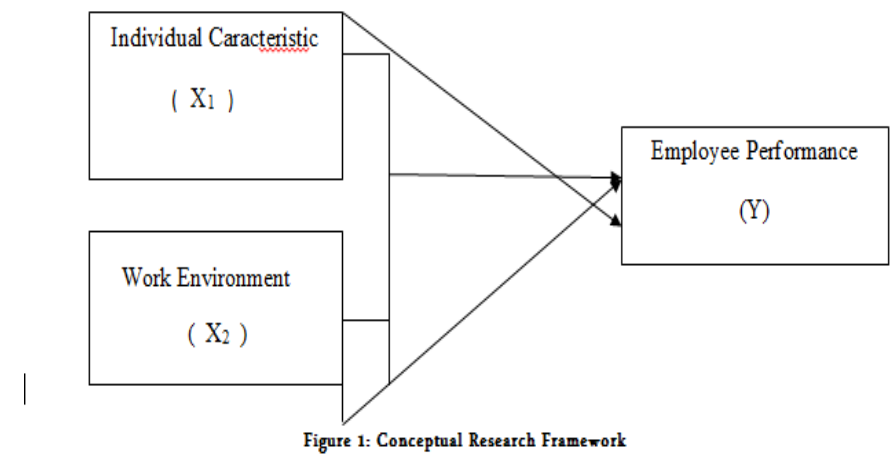

\section{Hypothesis}

Based on the formulation of the problem and conceptual framework presented earlier, then formulated the following hypothesis:

a. There is influence of individual characteristics on employee performance PTPN III (Persero) Medan.

b. There is influence of work environment to employee performance PTPN III (Persero) Medan.

c. There is influence of individual characteristics and work environment on employee performance PTPN III (Persero) Medan.

\section{RESEARCH METHODOLOGY}

\section{Research Approach}

The research approach used in this research is associative approach. According to Azuar Juliandi and Irfan (2013: 14) that the associative approach aims to examine how a variable has relevance or related to other variables or whether a variable is influenced by other variables or whether a variable is the cause of change of other variables.

\section{Place and Time of Research}

The research was conducted in PTPN III (Persero) Medan which is located at Jalan Sei Batang Hari No.2 Simpang Tanjung Medan Sunggal, Medan City of North Sumatra. The research starts from November 2017 to March 2018.

\section{Population and Sample}

The population is the whole set of elements that exhibit certain features that can be used to make a conclusion. In this study, the population is all employees of human resources department of PTPN III (Persero) Medan, amounting to 51 people. The sample is a portion of the total population that will be used as an object or research respondents. In this case the researchers determine the maximum sample of 51 people by using saturated sampling.

\section{Data Collection Technique}

To obtain complete and accurate data in this study, the researchers used data collection techniques using: 

a. Angket (Quesioner)
b. Documentation Study

To test whether the instrument measured in accordance with the purpose of measurement is done:
a. Instrument Validity
b. Instrument Reliability

Data Analysis Technique

Data analysis technique used in this research is quantitative data analysis, that is:

Classic assumption test:
a. Normality test
b. Multicollinearity test
c. Heteroscedasticity test
1. Hypothesis testing
a. Partial Significant Test (Test Statistic t)
b. Simultaneous Significant Test (Test statistic f)

2. Determination Coefficient Test $\left(\mathrm{R}^{2}\right)$

\section{RESEARCH RESULT AND DISCUSSION}

\section{Research Result}

\section{Classic Assumption Test}

\section{a. Normality Test}

Normality test aims to determine whether the distribution of a data follows or approaches the normal distribution. From the data processing with SPSS known that the data spread around the diagonal line and follow the direction of the diagonal line so as to meet the assumption of normality so that it can be followed by hypothesis testing. From Kolmogorov-Smirnov test with SPSS obtained asymp.Sig> 0.05 thus the data is normally distributed.

\section{b. Multicolinearity Test}

From result of processed data of SPSS obtained value of VIF> 0,10, it is stated that not happened multicollinearity.

\section{c. Heteroscedasticity Test}

From the result of SPSS processed data seen spreading point randomly and does not form a certain pattern clear and spread either above or below zero on $\mathrm{Y}$ axis, so regression model is suitable for independent variable and free variable.

\section{Multiple Linier Regression}

From result of processed data of SPSS, obtained by regression equation model is:

$\mathrm{Y}=8.147+0.588 \mathrm{X} \_1+0.155 \mathrm{X} \_2$. From the regression equation is obtained that the coefficient of individual characteristics gives a value of 0.588 and the coefficient of work environment gives a value of 0.155 , which means the better individual characteristics and work environment then the employee performance will increase.

\section{Hipothesis Testing}

\section{a. T-test}

From result of processed data of SPSS in can t_hitung $=4,312$ with t_table $=1,677$. Based on partial test result t_hitung $>t_{\text {_ }}$ (table) or 4,312> 1,677 with significant level $0,000<0,05$, so there is significant influence between individual characteristic to employee performance.

From result of processed data of SPSS in can t_hitung $=2,289$ with t_table $=1,677$. Based on the partial test results $t$ hitung $>t$ table or 2.289> 1.677 with significance level0.202>0.05, so there is a significant influence between the work environment on employee performance. 


\section{b. F-test}

From result of processed data of SPSS in can F_hitung $=31,421$ with $F_{-}$table $=3,191$. Based on the test results simultaneously $F_{-}$hitung $>$F_tabel or 31,421> 3,191 with significant 0.05 , so there is a significant influence between individual characteristics and work environment on employee performance.

\section{Determination Coefficient $\left(\mathbf{R}^{2}\right)$}

From result of processed data of SPSS got coefficient of determination equal to 0,429 , this mean $49,2 \%$ variation of employee performance variable (Y) determined by both independent variable that is individual characteristic (X1) and work environment (X2), while $50,8 \%$ by another variable.

\section{CONCLUSIONS AND SUGGESTIONS}

\section{Conclusions}

Based on the results of research and analysis of data that has been described, can be drawn the following conclusions:

a. The more individual characteristics are considered in a company, then the company's goals will be achieved and thus will improve employee performance.

b. The more work environments are noticed and upgraded in a company, then the company's goals will be achieved well.

c. The more individual characteristics and work environment are concerned, it will improve employee performance and the company's goals will be achieved perfectly.

\section{Suggestions}

a. In considering the individual characteristics of PTPN III III (Persero) Medan to keep the individual characteristics are always competitive and is expected to improve employee performance so that corporate goals will be achieved.

b. As for the working environment of PTPN III (Persero) always pay attention to work environment factors so that the better employee performance and company goals will be achieved.

\section{REFERENCES}

Abdullah, M Ma'Ruf. 2014. Manajemen Dan Evaluasi Kinerja Karyawan. Yogyakarta: Aswaja Pressindo.

Azuar, Juliandi Dan Irfan. 2011. Metodologi Penelitian Kuantitatif Untuk Ilmu-Ilmu Bisnis. Bandung: Ciptapustaka Media Perintis.

Danang Sunyoto. 2012. Manajemen Sumber Daya Manusia. Jakarta: Buku Seri.

Mangkunegara. 2011. Manajemen Sumber Daya Manusia Perusahaan, Edisi Kesepuluh. Bandung: Penerbit Rosdakarya.

Moeheriono. 2012. Pengukuran Kinerja, Edisi Revisi. Jakarta: Rawali Press.

Sutrisno Edi. 2011. Manajemen Sumber Daya Manusia, Edisi Pertama Cetakan Kedua. Jakarta: Kencana Prenada Media Group. 